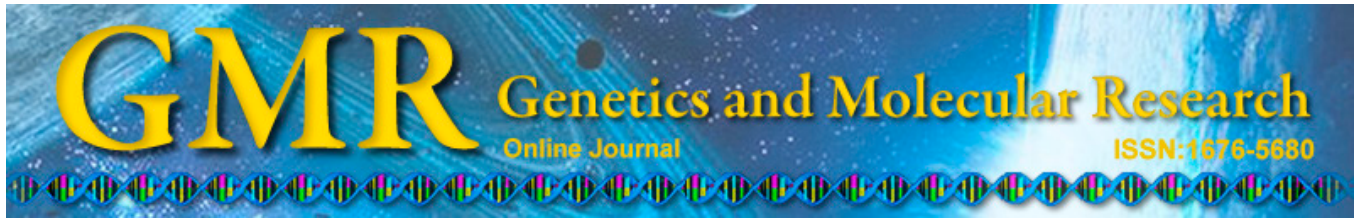

\title{
Overexpression of pucC improves the heterologous protein expression level in a Rhodobacter sphaeroides expression system
}

L. Cheng, G. Chen, G. Ding, Z. Zhao, T. Dong and Z. Hu

Key Laboratory of Biorheological Science and Technology

Ministry of Education, Bioengineering College, Chongqing University, Chongqing, China

Corresponding author: $\mathrm{Z} . \mathrm{Hu}$

E-mail: huzongli71@163.com / huzongli@cqu.edu.cn

Genet. Mol. Res. 14 (2): 4058-4067 (2015)

Received August 8, 2014

Accepted November 6, 2014

Published April 27, 2015

DOI http://dx.doi.org/10.4238/2015.April.27.21

\begin{abstract}
The Rhodobacter sphaeroides system has been used to express membrane proteins. However, its low yield has substantially limited its application. In order to promote the protein expression capability of this system, the puc $\mathrm{C}$ gene, which plays a crucial role in assembling the $R$. sphaeroides light-harvesting 2 complex (LH2), was overexpressed. To build a puc $\mathrm{C}$ overexpression strain, a puc $\mathrm{C}$ overexpression vector was constructed and transformed into $R$. sphaeroides CQU68. The overexpression efficiency was evaluated by quantitative real-time polymerase chain reaction. A well-used reporter $\beta$-glucuronidase (GUS) was fusion-expressed with LH2 to evaluate the heterologous protein expression level. As a result, the cell culture and protein in the $p u c \mathrm{C}$ overexpression strain showed much higher typical spectral absorption peaks at 800 and $850 \mathrm{~nm}$ compared with the nonoverexpression strain, suggesting a higher expression level of LH2GUS fusion protein in the pucC overexpression strain. This result was further confirmed by Western blot, which also showed a much higher level of heterologous protein expression in the $p u c \mathrm{C}$ overexpression
\end{abstract}


strain. We further compared GUS activity in $p u c \mathrm{C}$ overexpression and non-overexpression strains, the results of which showed that GUS activity in the $p u c \mathrm{C}$ overexpression strain was approximately ten-fold that in the non-overexpression strain. These results demonstrate that overexpressed puc C can promote heterologous protein expression levels in R. sphaeroides.

Key words: Heterologous protein expression; Rhodobacter sphaeroides Light-harvesting 2 complex assembly; pucC

\section{INTRODUCTION}

Recombinant proteins play an important role in biological and biomedical science. Currently, Escherichia coli and yeast are the most commonly used heterologous expression systems for producing recombinant proteins. However, E. coli and yeast systems have a limited capacity for producing membrane proteins (Dong et al., 1995).

Rhodobacter sphaeroides is a well-characterized photosynthetic bacterium that can be employed as an expression system for membrane proteins (Roy et al., 2008). When used as an expression system, $R$. sphaeroides has some unique advantages. First, this bacterium has multiple growth modes, including aerobic and an aerobic respiration, fermentation, and anoxygenic photosynthesis, and is widespread throughout the world. Second, the indomitable bacterium is able to survive for more than ten years at room temperature in a sealed container on the bench. Most importantly, heterologous proteins expressed in $R$. sphaeroides can be evaluated rapidly and in real time.

A heterologous protein was expressed in the form of a fusion protein with an $\alpha$-subunit or a $\beta$-subunit of light-harvesting complex 2 (LH2), which is a component of the photosynthetic apparatus of R. sphaeroides (Kiley and Kaplan, 1988; Boonstra et al., 1993). The LH2 complex has typical absorption at $\sim 800$ and $\sim 850 \mathrm{~nm}$, which can be used for spectral detection of the expression of LH2 as well as the presence of LH2 as a $\beta$-subunit in fusion proteins (Golecki et al., 1979; McGlynn et al., 1996; Hu et al., 2002). Thus, in previous studies, we have developed a rapid heterologous protein evaluation method in a $R$. sphaeroides expression system according to its spectral characteristics (Zhao et al., 2011). All these advantages firmly suggest that $R$. sphaeroides could be an excellent protein expression system. Unfortunately, the level of heterologous protein expression in $R$. sphaeroides is much lower than that in other hosts, which seriously limits its application.

The PucC protein plays a role in $R$. sphaeroides LH2 assembly. It governs the assembly of the $\alpha$ - and $\beta$-subunits at the intracytoplasmic membrane system to form the functional LH2 complex (Tichy et al., 1991; LeBlanc and Beatty, 1996; Jaschke et al., 2008). Knocking out pucC results in the inefficient formation of the LH2 complex as well as a failure of heterologous protein expression (Gibson et al., 1992; LeBlanc and Beatty, 1993), suggesting that the PucC protein might be an essential element in heterologous protein expression. However, there has been no research focus on the relationship between PucC and heterologous protein expression capability in $R$. sphaeroides.

In this paper, we describe our attempt to promote the heterologous protein expression level by overexpressing the $p u c \mathrm{C}$ gene in $R$. sphaeroides. The expression level of heterologous proteins was analyzed by spectral absorption, $\beta$-glucuronidase (GUS) activity detection, and 
Western blot. This research suggests that $p u c C$ overexpression can increase the heterologous protein expression levels in the $R$. sphaeroides expression system.

\section{MATERIAL AND METHODS}

\section{Strains, plasmids, and growth conditions}

Strains and plasmids used in this study are listed in Table 1 . The $R$. sphaeroides strains were grown in $\mathrm{M} 22+$ liquid medium at $34^{\circ} \mathrm{C}$ supplemented with $0.1 \%$ casamino acids (Hunter and Turner, 1988). Semi-aerobic and aerobic cultures were performed as previously described (Pasternak et al., 1999). E. coli strain was grown aerobically at $37^{\circ} \mathrm{C}$ in Luria-Bertani medium. Antibiotics were added to the growth media at the following concentrations: ampicillin, 100 $\mu \mathrm{g} / \mathrm{mL}$ for $E$. coli; tetracycline, $10 \mu \mathrm{g} / \mathrm{mL}$ for $E$. coli and $1 \mu \mathrm{g} / \mathrm{mL}$ for $R$. sphaeroides; neomycin, $20 \mu \mathrm{g} / \mathrm{mL}$ for $R$. sphaeroides; streptomycin, $5 \mu \mathrm{g} / \mathrm{mL}$ for $R$. sphaeroides; and gentamycin, $30 \mu \mathrm{g} / \mathrm{mL}$ for $R$. sphaeroides.

\begin{tabular}{|c|c|c|}
\hline Strains or plasmid & Relevant characteristic & Reference \\
\hline \multicolumn{3}{|l|}{ R. Sphaeroides } \\
\hline CQU68 & $\begin{array}{l}\text { Genomic deletion of pufBALMX, puclBA, and puc } 2 B A, \\
\text { insertion of } \mathrm{Nm}^{\mathrm{r}}, \mathrm{Sm}^{\mathrm{r}} \text {, and } \mathrm{Gm}^{\mathrm{r}} \text { gene. }\end{array}$ & Zhao et al., 2011 \\
\hline CQU68 /pRKрисРpucC & Containing plasmid of pRKрисРpucC. & This study \\
\hline pucC non-overexpression strain & 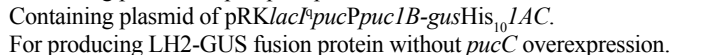 & This study \\
\hline pucC overexpression strain & $\begin{array}{l}\text { Containing plasmid of pRKlacl } I^{\mathrm{q}} p u c \mathrm{P} p u c 1 B \text {-gusHis } 10 \mathrm{~A} / \mathrm{pRK} p u c \mathrm{P} p u c C \text {. } \\
\text { For producing LH2-GUS fusion protein complex with } p u c C \text { overexpression. }\end{array}$ & This study \\
\hline E. coli & Strain used for cloning. & \\
\hline $\mathrm{DH} 5 \alpha$ & Tra + strain used for plasmid mobilization. & Eraso and Kaplan, 1994 \\
\hline S17-1 & & Simon et al., 1983 \\
\hline Plasmids & Cloning vector, $\mathrm{Amp}^{\mathrm{r}}$ & Yanisch-Perron et al., 1985 \\
\hline pUC19 & $\mathrm{Mob}+, \mathrm{Tc}^{\mathrm{r}}$, vector & Keen et al., 1988 \\
\hline pRK415 & pUC19 cloning vector containing puc $\mathrm{P}$ promoter, $p u c C$ and terminator. & This study \\
\hline pUC19-PPT & $\begin{array}{l}\text { pRK } 415 \text { derivative, expression vector containing } p u c \mathrm{P} \text { promoter, } \\
\text { pucC and terminator. }\end{array}$ & Wang et al., 2009a \\
\hline pRKрисРрисC & 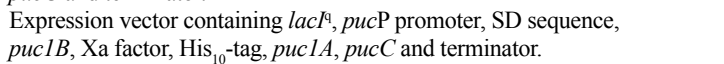 & Hu et al., 2010 \\
\hline $\mathrm{pRK}$ acl ${ }^{\mathrm{a}}$ pucPpuclB $\mathrm{His}_{10} A C$ & For producing LH2-GUS fusion protein without pucC overexpression. & This study \\
\hline 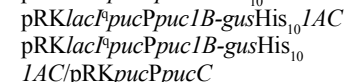 & For producing LH2-GUS fusion protein complex with pucC overexpression. & This study \\
\hline
\end{tabular}

\section{Vector construction and conjugation techniques}

In this study, GUS was used as a reporter protein. The gus gene was amplified with primer pairs from previous research (Cao et al., 2012). For the purification of heterologous protein, the His-tag was also introduced. We cloned and inserted gus into the previously used expression vector $\mathrm{pRK} l a c I^{\mathrm{a}} p u c \mathrm{P} p u c 1 B \mathrm{His}_{10} 1 A C$ (Figure 1A) (Hu et al., 2010) to produce the novel expression vector pRKlacl ${ }^{\mathrm{q}}$ pucPpuclB-gusHis ${ }_{10} 1 A C$ (Figure 1B). The new expression vector was introduced into $R$. sphaeroides CQU68 by conjugative transfer as described previously (Hunter and Turner, 1988) for producing LH2-GUS fusion protein without pucC overexpression (non-overexpression). 
A

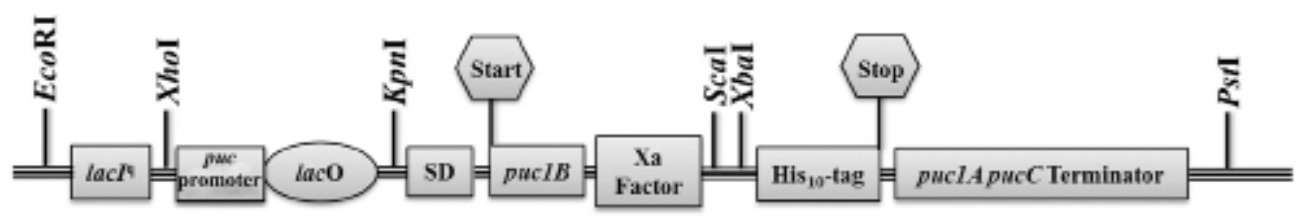

B

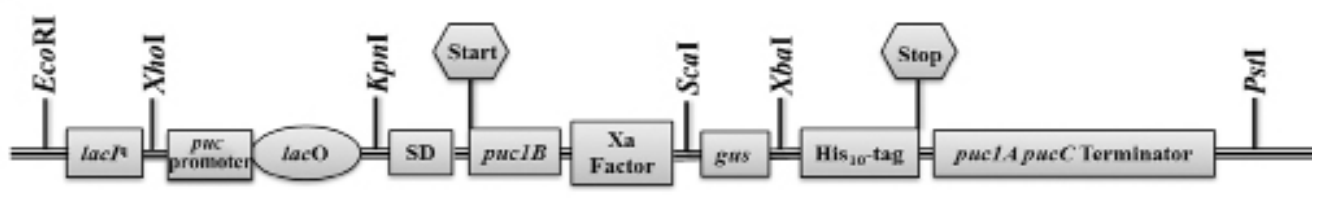

$\mathrm{C}$

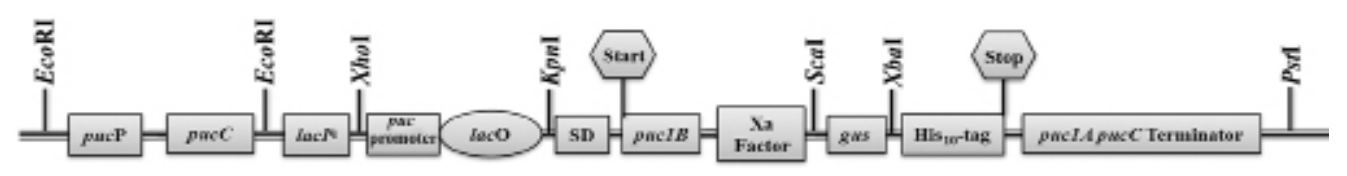

Figure 1. Schematic representation of the expression vector constructs. A. Construction of pRKlacI ${ }^{\mathrm{q}} p u c \mathrm{P} p u c 1 B \mathrm{His}_{10} 1 A C$ containing a hybrid promoter comprising E. coli lac $I^{\mathrm{q}}$ and $l a c \mathrm{O}$, puc $\mathrm{P}$ promoter of $R$. sphaeroides, and structural genes puclB, puclA, and pucC. B. Construction of pRKlacI ${ }^{\mathrm{p}}$ pucPpuclBgusHis $_{10} 1 A C$ possessing a foreign GUS-encoding gene inserted between the $S c a \mathrm{I}$ and $X b a \mathrm{I}$ sites of the

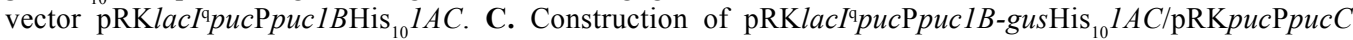
possessing a separate $p u c \mathrm{P}$ promoter, $p u c \mathrm{C}$ gene, and terminator inserted into the EcoRI site of the vector pRKlacI ${ }^{\mathrm{q}}$ pucPpuclB-gus $\mathrm{His}_{10} 1 A C$.

The fragment containing puc promoter, $p u c \mathrm{C}$ gene, and terminator was amplified from the $\mathrm{pRK}$ рисPрисC vector, which was derived from pRK415 according to previous research (Wang et al., 2009a) (primers: pRKpucC-F and pRKрисC-R, Table 2). This fragment was then ligated into pUC19 to make pUC19-PPT, which was further introduced into pRKlac ${ }^{\mathrm{q}-}$ pucPpuclB-gusHis ${ }_{10} 1 A C$ to yield the $p u c C$ overexpression vector $\mathrm{pRK} l a c I^{\mathrm{a}} p u c \mathrm{P} p u c 1 B$-gus $\mathrm{H}$ is $_{10} 1 A C / \mathrm{pRK}$ pucPpucC (Figure 1C). This vector was introduced into $R$. sphaeroides CQU68 by conjugative transfer for producing the LH2-GUS fusion protein under the condition of pucC overexpression.

Table 2. Primers used in this study.

\begin{tabular}{|c|c|c|}
\hline Primer name & Sequence & Information \\
\hline pRKрисC-F & 5'-CGGAATTCAAGGCCTCGGACACCCTCGTTT-3' & Cloned pucP promoter \\
\hline pRKрисC-R & 5'-CGGAATTCCCAAGCTTATCGATTTCCAT-3' & pucC, and terminator \\
\hline RT-gus-F & 5'-AGACAGACCCGTCAAATCG-3' & For qRT-PCR analysis \\
\hline RT-gus-R & 5'-TTCCAGGTTCAGTCCATAGC-3' & For qRT-PCR analysis \\
\hline RT-rpoz-F & 5'-GCGACAATGACAAGAACC-3' & For qRT-PCR analysis \\
\hline RT-rpoz-R & 5'-GCCATCTGATCCTCTTCC-3' & For qRT-PCR analysis \\
\hline RT-pucC-F & 5'-CCTGATGTATGTGGTGCT-3' & For qRT-PCR analysis \\
\hline RT-pucC-R & 5'-CCGAGATGACCTTGATGA-3' & For qRT-PCR analysis \\
\hline
\end{tabular}

qRT-PCR $=$ quantitative real-time polymerase chain reaction. 


\section{Expression of LH2-GUS fusion protein}

A single transconjugant colony was inoculated into M22+ liquid medium and grown under aerobic conditions. For the expression of LH2-GUS fusion protein, cell cultures were shifted from aerobic conditions to semi-aerobic conditions at an optical density of the sample measured at a wavelength of $600 \mathrm{~nm}\left(\mathrm{OD}_{600}\right)$ of $0.8-1.0$, and continuously induced by $1.0 \mathrm{mM}$ isopropyl $\beta$-D-1-thiogalactopyranoside (IPTG) for $0,6,12,18,24,30$, and $36 \mathrm{~h}$. The absorption spectrum was recorded on a Perkin Elmer lambda 900 UV/VIS spectrometer (USA).

\section{RNA extraction and quantitative real-time polymerase chain reaction (qRT-PCR)}

Samples were collected for RNA isolation at $0,6,12,18,24,30$, and $36 \mathrm{~h}$ after adding IPTG. Total RNA was extracted using RNAiso Plus (TaKaRa). The complementary DNA (cDNA) was synthesized using a random primer (TaKaRa) and M-MuLV Reverse Transcriptase (Promega). The PCR mixture contained 7.5 $\mu \mathrm{L} 2 \mathrm{X}$ SYBR Premix Ex Taq II (TaKaRa), $500 \mu \mathrm{M}$ of each specific primer, and $1 \mu \mathrm{L}$ diluted cDNA in a $15 \mu \mathrm{L}$ final volume. qRT-PCR analyses were performed in triplicate in a CFX96 Real-Time System (Bio-Rad) under the following conditions: $3 \mathrm{~min}$ at $98^{\circ} \mathrm{C}$, followed by 40 cycles of $98^{\circ} \mathrm{C}(15 \mathrm{~s}), 56^{\circ} \mathrm{C}(15 \mathrm{~s})$, and $72^{\circ} \mathrm{C}(15 \mathrm{~s})$ on a $96-$ well optical reaction plate (Bio-Rad). The expression of puc C and gus was normalized to rpoz as a housekeeping gene (Wang et al., 2009b). Primers for pucC, gus, and rpoz are listed in Table 2.

\section{Protein extraction, purification, and Western blot}

Crude proteins from $R$. sphaeroides were prepared as previously described (Zhao et al., 2010). Briefly, 4 L IPTG-induced cell culture was collected by centrifuging. The precipitate was re-suspended in $20 \mathrm{mM}$ Tris buffer, $\mathrm{pH} 8.0$, in the presence of $100 \mathrm{mM} \mathrm{NaCl}, 1 \mathrm{mM}$ phenylmethyl sulfonylfluoride, $50 \mu \mathrm{g} / \mathrm{mL}$ DNase I, and $10 \mu \mathrm{g} / \mathrm{mL}$ RNase I, and subsequently broken by three passages with a high-pressure homogenizer at 1200 bar. To remove the cell debris, centrifuging was performed twice at $17,000 \mathrm{~g}$ and $4^{\circ} \mathrm{C}$ for $15 \mathrm{~min}$. Then the supernatant was precipitated by ultra-centrifugation at $160,000 \mathrm{~g}$ and $4^{\circ} \mathrm{C}$ for $90 \mathrm{~min}$. After that, the membrane pellets were re-suspended with $20 \mathrm{mM}$ Tris buffer as above to a final protein concentration of $5 \mathrm{mg} / \mathrm{mL}$ (determined by BCA Protein Assay Kit; VigoRous, China). The absorption spectrum of the extracted protein was recorded on a Perkin Elmer lambda 900 UV/VIS spectrometer. For protein purification, total protein was solubilized with $1.0 \%(\mathrm{v} / \mathrm{v})$ lauryldimethylamine $\mathrm{N}$-oxide (LDAO) and purified by Ni-IDA agarose resin (Amersham Biosciences, USA).

For Western blot, $30 \mu \mathrm{g}$ total protein was separated by $12 \%$ sodium dodecyl sulfate polyacrylamide gel electrophoresis (SDS-PAGE) gel and transferred to a $0.45-\mu \mathrm{m}$ polyvinylidene difluoride membrane after electrophoresis. His-tag monoclonal antibody anti-His antibody and goat anti-mouse IgG-alkaline phosphatase (Proteintech, USA) were used as the primary and the secondary antibodies, respectively. Immunoreactivity was determined by the ECL method (Amersham Biosciences, USA).

\section{Fluorometric GUS quantitation assay}

Whole-cell extraction of transformants and fluorometric analysis of GUS activ- 
ity were carried out according to previous research (Jefferson, 1987; Horvath and Riezman, 1994). 4-Methylumbelliferyl- $\beta$-D-glucuronide (MUG), which is cleaved by the GUS enzyme to release methylumbelliferone (MU) and glucuronic acid, was used as the fluorimetric GUS assay substrate. The GUS activity of total protein was measured in both the pucC overexpression and non-overexpression strains. To quantify the GUS activity, a calibration graph of known concentrations of the fluorescent reaction product NaMU dissolved in GUS extraction buffer was produced. To quantify the fluorescent signal, an ALEXA filter set (excitation 350 $\mathrm{nm}$ and emission $440 \mathrm{~nm}$, Stratagene) was used. Standard errors were derived from means of 20 readings and were reproducible from one experiment to the next.

\section{RESULTS}

\section{pucC gene was successfully overexpressed in the overexpression strain}

qRT-PCR was performed to determine the overexpression efficiency of pucC. As shown in Figure 2A, pucC expression exhibited the same expression trend in the strain with or without puc $\mathrm{C}$ overexpression. The expression level reached a peak at $18 \mathrm{~h}$ after adding IPTG and remained at a high level between 18 and $36 \mathrm{~h}$. However, the pucC expression level in the pucC overexpression strain was much higher than in the non-overexpression strain, which illustrated that $p u c \mathrm{C}$ was successfully overexpressed. Meanwhile, pucC overexpression led to increasing gus expression, which also reached a peak at $18 \mathrm{~h}$ (Figure 2B), indicating that $18 \mathrm{~h}$ could be the best duration for protein expression.

A

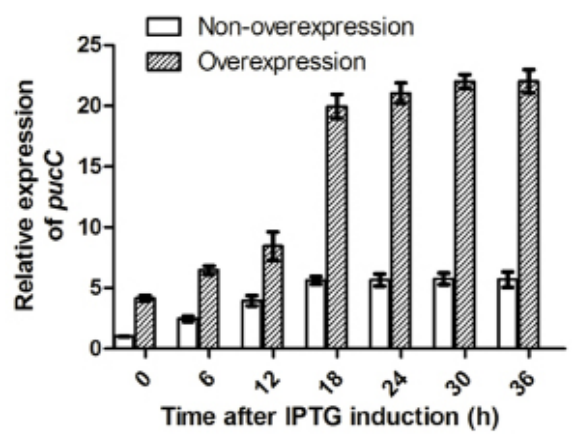

B

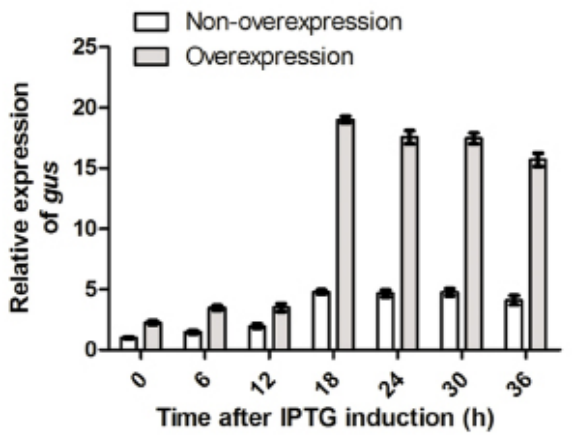

Figure 2. Expression profile of puc $\mathrm{C}$ and gus during cell culture. A. Relative expression of puc $\mathrm{C}$ after isopropyl $\beta$-D-1-thiogalactopyranoside (IPTG) induction. B. Relative expression of gus after IPTG induction. The expression of $p u c \mathrm{C}$ and gus gene was normalized to rpoz as a housekeeping gene. The expression level of pucC and gus at $0 \mathrm{~h}$ in the non-overexpression strain was set to $100 \%$.

\section{pucC gene overexpression can promote the LH2-GUS fusion protein expression level in $R$. sphaeroides}

Absorbance spectroscopy was employed to detect whether the abundance of LH2GUS fusion protein was enriched by pucC overexpression. According to the absorbance spec- 
troscopy, the cell cultures from the $\mathrm{pucC}$ overexpression strain and the non-overexpression strain shared the same spectral pattern at 800 and $850 \mathrm{~nm}$, which indicated the presence of LH2-GUS fusion protein complex in these cell cultures. Compared to the non-overexpression strain, the absorption peaks of the $p u c \mathrm{C}$ overexpression strain were much higher, suggesting the LH2-GUS fusion protein was enriched by pucC overexpression. For accurate measurement, the total protein was extracted and detected from $p u c \mathrm{C}$ overexpression and non-overexpression strains. As shown in Figure 3A, protein from the two strains displayed spectral properties similar to those from the cell culture. The absorption peaks of protein purified from the pucC overexpression strain presented a much higher peak. This result also verified that the capability of $R$. sphaeroides to produce LH2-GUS fusion protein can be promoted by pucC overexpression.

\section{A}

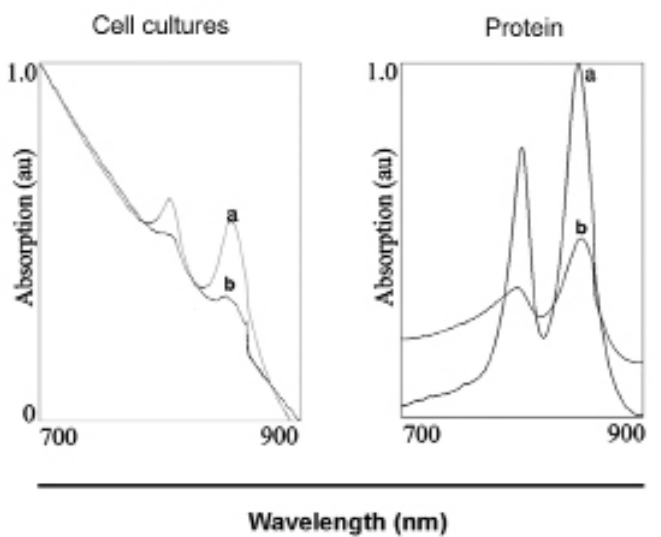

B
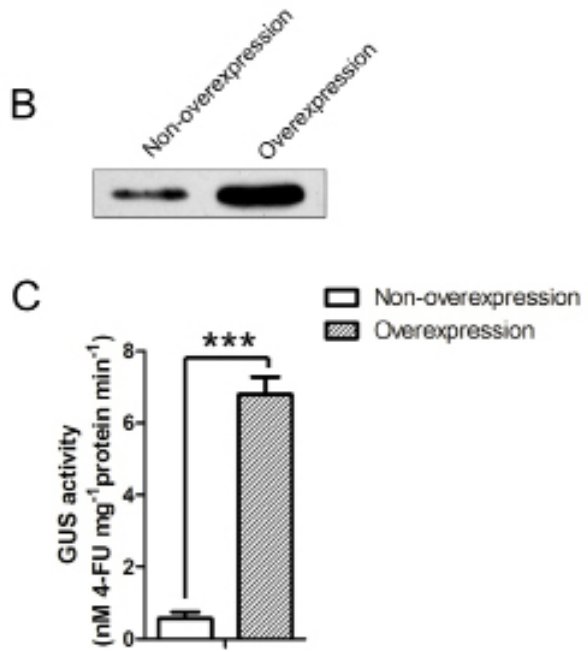

Figure 3. Overexpression of $p u c \mathrm{C}$ can promote the expression level of LH2-GUS fusion protein. A. Spectral absorption of cell cultures and total protein; a represents absorption of cell cultures or total protein from the pucC overexpression strain; $b$ represents absorption of cell cultures or total protein from the non-overexpression strain; $\mathrm{au}=$ absorbance units. B. Western blot analysis of LH2-GUS fusion protein; $30 \mu \mathrm{g}$ total protein was used for each sample. C. GUS activity in the $p u c \mathrm{C}$ overexpression and non-overexpression strains.

A Western blot was performed to compare the expression level of LH2-GUS fusion protein in the $p u c \mathrm{C}$ overexpression and non-overexpression strains. The LH2-GUS fusion protein from the $p u c \mathrm{C}$ overexpression strain showed a much wider and brighter band than the non-overexpression strain (Figure 3B), suggesting that the yield of heterologous protein is markedly promoted by pucC overexpression.

GUS activity was evaluated in the two strains (Figure 3C). The GUS activity in the pucC overexpression strain was approximately ten-fold that in the non-overexpression strain. There was more LH2-GUS fusion protein in the $p u c \mathrm{C}$ overexpression strain, suggesting that $p u c \mathrm{C}$ overexpression can promote heterologous protein expression.

In conclusion, the spectral absorption, Western blot, and GUS activity detection firmly proved that $p u c \mathrm{C}$ overexpression enhances the expression level of the LH2-GUS fusion protein in the $R$. sphaeroides expression system. 


\section{pucC overexpression does not affect the purification of the heterologous protein}

As the LH2-GUS fusion protein expression level can be promoted by pucC overexpression, we wondered whether pucC overexpression might affect heterologous protein purification. After His-tag purification, the purified LH2-GUS fusion protein was examined by SDS-PAGE. As shown in Figure 4, a single band of approximately $80 \mathrm{kD}$ was observed in the puc C overexpression lane and no other bands were found, suggesting that the expressed protein can be easily purified and $p u c \mathrm{C}$ overexpression does not cause contamination by other proteins.

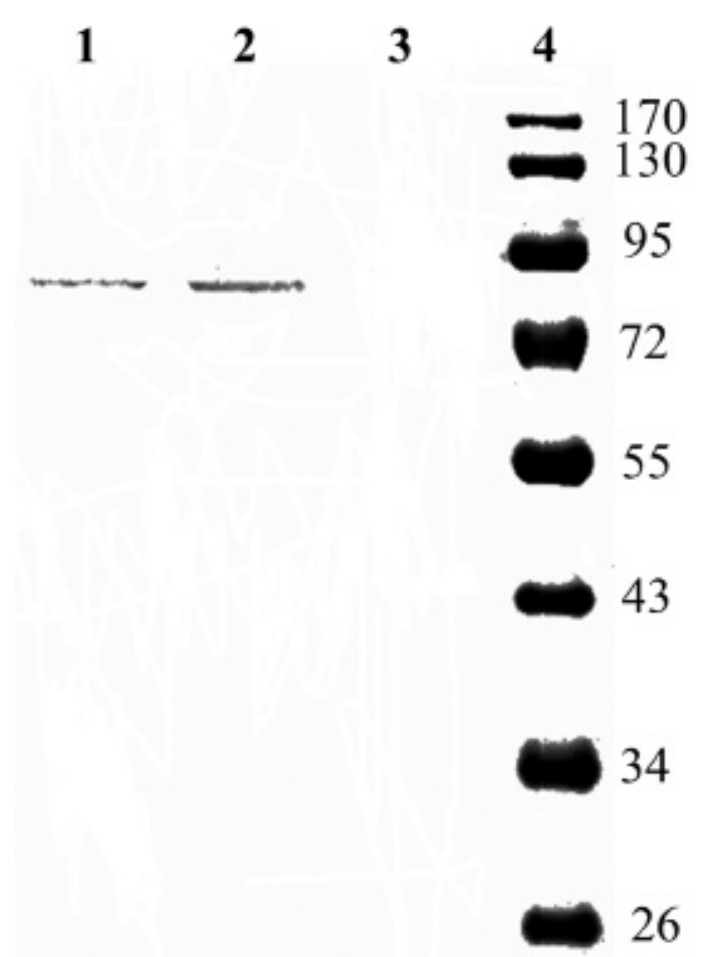

Figure 4. Sodium dodecyl sulfate-polyacrylamide gel electrophoresis analysis of the purified LH2-GUS fusion protein. Lane 1 = protein purified from the non-overexpression strain; lane $2=$ protein purified from the puc $\mathrm{C}$ overexpression strain; lane 3 = negative control purified from CQU68; lane 4 = molecular weight markers.

\section{DISCUSSION}

The Puc operon of R. sphaeroides consists of five structural genes: pucA, pucB, pucC, $p u c D$, and $p u c E$. The $p u c A$ and $p u c B$ genes encode the $\alpha$ - and $\beta$-subunits, respectively. The $p u c \mathrm{C}$ gene encodes the pucC protein, which governs the assembly of the $\alpha$ - and $\beta$-subunits in the intracytoplasmic membrane system, and plays a key role in functional LH2 assembly. In a previous study, we reported the construction of an LH2 polypeptide expression vector that contained a reengineered lacI ${ }^{\mathrm{q}}-$ puc promoter-lac operator hybrid promoter, allowing the puc operon to be regulated by both IPTG and oxygen level (Hu et al., 2010). Later, we established a novel $R$. sphaeroides expression system with the above hybrid promoter, and found that 
the production of heterologous protein could be rapidly detected through LH2 absorption at $\sim 800$ and $\sim 850 \mathrm{~nm}$. This typical absorption can be used as a monitor for rapid and real-time evaluation of heterologous protein expression levels (Zhao et al., 2011). However, although $R$. sphaeroides can be used as a heterologous protein expression system, the production of which can be easily evaluated, the relatively low protein expression level becomes the major limitation of this expression system.

In this study, we overexpressed the pucC gene with the aim of promoting the heterologous protein expression level of $R$. sphaeroides. A well-used reporter protein GUS, expressed as a fusion protein with $\mathrm{LH} 2$, was used to evaluate the effect of puc C overexpression on heterologous protein expression.

qRT-PCR identified the success of pucC overexpression, which led directly to an increase in gus mRNA. Subsequently, we adopted three steps to investigate whether the overexpressed pucC could promote the LH2-GUS fusion protein. Firstly, since the heterologous protein expression level can be detected through a specific typical absorption (Zhao et al., 2011), infrared absorption was employed to detect the LH2-GUS fusion protein expression level in the pucC overexpression and non-overexpression strains. Both the cell cultures and total protein showed higher absorption peaks with $p u c \mathrm{C}$ overexpression, suggesting that the $p u c \mathrm{C}$ overexpression strain can express higher levels of heterologous protein. Secondly, Western blot analysis was used to evaluate the difference in LH2-GUS fusion protein expression level between the pucC overexpression and non-overexpression strains. Although identical amounts of total protein were used, the $p u c \mathrm{C}$ overexpression group showed a much wider and brighter band, indicating that there was a higher content of LH2-GUS fusion protein in the total protein extracted from the pucC overexpression strain. Finally, as GUS is a well-used reporter protein, we directly detected and compared the GUS activity in the two strains. The GUS activity in the protein from the pucC overexpression strain was more than 10 times that of the protein from the non-overexpression strain. This result further verified the higher heterologous protein level in the pucC overexpression strain. In conclusion, these results firmly demonstrate that $p u c \mathrm{C}$ overexpression does indeed promote the heterologous protein expression capability of $R$. sphaeroides.

Based on these experiments, we conclude that the expression level of heterologous proteins can be improved by pucC overexpression in the $R$. sphaeroides expression system. The new strategy we have established has potential for promoting the expression level of heterologous membrane protein in $R$. sphaeroides.

\section{ACKNOWLEDGMENTS}

We thank Prof. C. Neil Hunter (The University of Sheffield, UK) for the DD13 strain. Research supported by the National Natural Science Foundation of China (\#31171968, \#31100089) and the Natural Science Foundation of Chongqing of China (\#CSTC2013JCYJA00011).

\section{REFERENCES}

Boonstra AF, Visschers RW, Calkoen F and van Grondelle R (1993). Structural characterization of the B800-850 and B875 light-harvesting antenna complexes from Rhodobacter sphaeroides by electron-microscopy. Biochim. Biophys. Acta 1142: 181-188.

Cao Y, Jiao R and Xia Y (2012). A strong promoter, PMagpd, provides a tool for high gene expression in entomopathogenic fungus, Metarhizium acridum. Biotechnol. Lett. 34: 557-562. 
Dong H, Nilsson L and Kurland CG (1995). Gratuitous overexpression of genes in Escherichia coli leads to growth inhibition and ribosome destruction. J. Bacteriol. 177: 1497-1504.

Eraso JM and Kaplan S (1994). prrA, a putative response regulator involved in oxygen regulation of photosynthesis gene expression in Rhodobacter sphaeroides. J. Bacteriol. 176: 32-43.

Gibson LC, McGlynn P, Chaudhri M and Hunter CN (1992). A putative anaerobic coproporphyrinogen III oxidase in Rhodobacter sphaeroides. II. Analysis of a region of the genome encoding hemF and the puc operon. Mol. Microbiol. 6: 3171-3186.

Golecki J, Drews G and Buhler R (1979). The size and number of intramembrane particles in cells of the photosynthetic bacterium Rhodopseudomonas capsulata studied by freeze-fracture electron microscopy. Cytobiologie 18: 381-389.

Horvath A and Riezman H (1994). Rapid protein extraction from Saccharomyces cerevisiae. Yeast 10: 1305-1310.

Hu X, Ritz T, Damjanovic A, Autenrieth F, et al. (2002). Photosynthetic apparatus of purple bacteria. Q. Rev. Biophys. 35: $1-62$.

Hu Z, Zhao Z, Pan Y and Tu Y (2010). A powerful hybrid puc operon promoter tightly regulated by both IPTG and low oxygen level. Biochemistry 75: 519-522.

Hunter CN and Turner G (1988). Transfer of genes coding for apoproteins of reaction centre and light-harvesting LH1 complexes to Rhodobacter sphaeroides. Microbiology 134: 1471-1480.

Jaschke PR, Leblanc HN, Lang AS and Beatty JT (2008). The PucC protein of Rhodobacter capsulatus mitigates an inhibitory effect of light-harvesting 2 alpha and beta proteins on light-harvesting complex 1. Photosynth. Res 95 : 279-284.

Jefferson RA (1987). Assaying chimeric genes in plants: the GUS gene fusion system. Plant Mol. Biol. Rep. 5: 387-405.

Keen NT, Tamaki S, Kobayashi D and Trollinger D (1988). Improved broad-host-range plasmids for DNA cloning in gram-negative bacteria. Gene 70: 191-197.

Kiley PJ and Kaplan S (1988). Molecular genetics of photosynthetic membrane biosynthesis in Rhodobacter sphaeroides. Microbiol. Rev. 52: 50-69.

LeBlanc HN and Beatty JT (1993). Rhodobacter capsulatus puc operon: promoter location, transcript sizes and effects of deletions on photosynthetic growth. J. Gen. Microbiol. 139: 101-109.

LeBlanc HN and Beatty JT (1996). Topological analysis of the Rhodobacter capsulatus PucC protein and effects of C-terminal deletions on light-harvesting complex II. J. Bacteriol. 178: 4801-4806.

McGlynn P, Westerhuis WH, Jones MR and Hunter CN (1996). Consequences for the organization of reaction center-light harvesting antenna 1 (LH1) core complexes of Rhodobacter sphaeroides arising from deletion of amino acid residues from the C terminus of the LH1 alpha polypeptide. J. Biol. Chem. 271: 3285-3292.

Pasternak C, Haberzettl K and Klug G (1999). Thioredoxin is involved in oxygen-regulated formation of the photosynthetic apparatus of Rhodobacter sphaeroides. J. Bacteriol. 181: 100-106.

Roy A, Shukla AK, Haase W and Michel H (2008). Employing Rhodobacter sphaeroides to functionally express and purify human G protein-coupled receptors. Biol. Chem. 389: 69-78.

Simon R, Priefer U and Pühler A (1983). A broad host range mobilization system for in vivo genetic engineering: transposon mutagenesis in Gram negative bacteria. Nat. Biotechnol. 1: 784-791.

Tichy HV, Albien KU, Gad'on N and Drews G (1991). Analysis of the Rhodobacter capsulatus puc operon: the pucC gene plays a central role in the regulation of LHII (B800-850 complex) expression. EMBO J. 10: 2949-2955.

Wang W, Hu Z, Li J, Chen X, et al. (2009a). Characteristics of light-harvesting complex II mutant of Rhodobacter sphaeroides with alterations at the transmembrane helices of beta-subunit. Biochemistry 74: 807-812.

Wang W, Hu Z, Li J and Chen G (2009b). Expression characterization and actual function of the second pucBA in Rhodobacter sphaeroides. Biosci. Rep. 29: 165-172.

Yanisch-Perron C, Vieira J and Messing J (1985). Improved M13 phage cloning vectors and host strains: nucleotide sequences of the M13mp18 and pUC19 vectors. Gene 33: 103-119.

Zhao Z, Hu Z, Liang Y, Hu T, et al. (2010). One-step purification of functional light-harvesting 2 complex from Rhodobacter sphaeroides. Protein Pept. Lett. 17: 444-448.

Zhao Z, Hu Z, Nie X, Cheng L, et al. (2011). A novel rhodobacter sphaeroides expression system for real-time evaluation of heterologous protein expression levels. Protein Pept. Lett. 18: 568-572. 